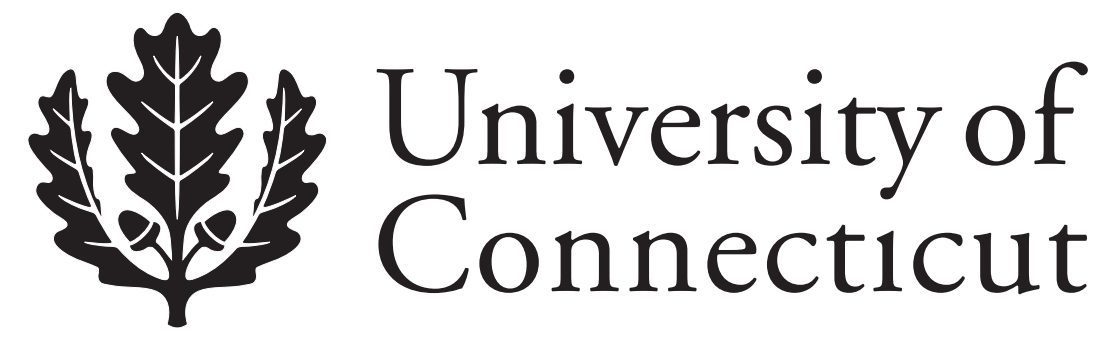

Department of Economics Working Paper Series

\title{
Optimal Attorney Advertising
}

Michael P. Stone

University of Connecticut

Working Paper 2010-14

July 2010

341 Mansfield Road, Unit 1063

Storrs, CT 06269-1063

Phone: (860) 486-3022

Fax: (860) 486-4463

http://www.econ.uconn.edu/

This working paper is indexed on RePEc, http://repec.org/ 


\begin{abstract}
Attorney advertising routinely targets tort victims. In this paper, a theoretical model is developed which incorporates advertising intensity, litigation costs, and an endogenous number of lawsuits. Since advertising induces victims to bring suit, it increases the level of injurer care. However, litigation costs are also incurred. At the optimum, the marginal benefit of deterrence equals the sum of the marginal costs of litigation and advertising. It is shown that even though blanket prohibitions on attorney advertising are likely suboptimal, ethical regulations which increase the marginal cost of advertising may be justified. Nevertheless, despite the widespread use of legal services advertising, it is unclear whether law firms are currently advertising excessively or inefficiently low. Whether firms are advertising excessively from a social standpoint is a purely empirical question.
\end{abstract}

Journal of Economic Literature Classification: K13, L84

Keywords: Tort, Liability, Advertising, Attorneys, Lawyer, Legal Services 


\section{OPTIMAL ATTORNEY ADVERTISING}

\section{A. INTRODUCTION}

Attorneys utilize a variety of media to advertise their legal services, including television, the Yellow Pages, the internet, billboards, and others. Many of these advertisements target the attention of tort victims, inquiring whether they are "Injured?" and if so, to "Call us today for a free consultation!" Proponents of attorney advertising argue that it provides valuable information regarding legal services to the poor and uneducated segments of society. On the other end of the spectrum, opponents to the widespread use of attorney advertising maintain, among other things, that it tarnishes the reputation of the legal profession, decreases the quality of legal services, and increases court caseloads. In this paper, these specific contentions are put aside, but the overarching theoretical issue is addressed. What is the optimal level of attorney advertising?

To develop a theory of optimal attorney advertising, this paper is organized as follows.

In Part B, attorney advertising is discussed in a historical context. Before the United States Supreme Court's ruling in Bates v. State Bar of Arizona (1977), ${ }^{1}$ advertising by attorneys was explicitly prohibited. But, since the Bates decision, which held that attorney advertising was a protected form of commercial free speech, attorney advertising expenditures have increased dramatically. In Part $\mathrm{C}$, a brief literature review of the economics of advertising - with special attention to legal services - is provided. While the economic literature is rife with articles focusing on the empirical impact of advertising on the price and quality of legal services, the literature is devoid of a thorough theoretical analysis of the welfare implications of attorney advertising. Then, in Part D, a theoretical model is presented. It is shown that blanket

\footnotetext{
${ }^{1} 433$ U.S. 350 (1977).
} 
prohibitions on attorney advertising are likely suboptimal. At the same time, ethical regulations, particularly those which increase the marginal cost of advertising, may be socially desirable. But, from a social standpoint, it is unclear whether firms are advertising excessively or inefficiently low.

\section{B. Attorney Advertising, Historically}

Over roughly the last half century, there have been drastic legal changes regarding the permissibility of attorney advertising. Under the early English system, attorneys were not viewed as businessmen. Rather, they were considered public servants of a learned profession (Calvani, Langenfeld, and Shuford, 1988: p. 762). As a result, tradition and etiquette, as opposed to formal regulations, governed the dignity of the bar (Calvani, Langenfeld, and Shuford, 1988: p. 762). This custom was incorporated into the early American practice of law.

Without constitutional protection on advertising, a unified prohibition on attorney advertising was codified by the early $20^{\text {th }}$ century. In 1908, the American Bar Association explicitly prohibited attorney advertising in Canon 27 of its Canons of Professional Ethics (Cebula, 1988: p. 503). The constitutionality of this prohibition was not an issue during the early-to-mid $20^{\text {th }}$ century since commercial free speech was outside the purview of the First Amendment. As a result, Canon 27 was soon adopted by every state (Calvani, Langenfeld, and Shuford, 1988: p. 763). ${ }^{2}$

The prohibition on attorney advertising did not extend into the late $20^{\text {th }}$ century. In the 1970s, the United States Department of Justice brought an antitrust action against the American Bar Association alleging that its advertising restrictions were anticompetitive (Lidsky and

\footnotetext{
${ }^{2}$ It should be noted that in 1969, the American Bar Association revised its Canons of Professional Ethics by adopting a Model Code of Professional Responsibility. With respect to attorney advertising, the particular differences between these two authorities are, for the purposes of this paper, arguably negligible.
} 
Peterson, 2008: pp. 5-6). The suit was never resolved, however, since states altered their advertising restrictions in light of the United States Supreme Court's ruling in Bates v. State Bar of Arizona. In Bates, the United States Supreme Court held that attorney advertising was a protected form of commercial free speech, and accordingly, an Arizona advertising prohibition was struck down as unconstitutional. ${ }^{3}$ This ruling effectively marked the end of blanket prohibitions on attorney advertising.

In the aftermath of Bates, a number of challenges arose. ${ }^{4}$ These cases reasoned that while blanket prohibitions on attorney advertising were unconstitutional, states were nonetheless permitted to regulate advertising in order to protect consumers from false, deceptive, or misleading statements. For instance, in Ohralik v. Ohio State Bar Association, ${ }^{5}$ the United States Supreme Court held that attorneys may be disciplined for the in-person solicitation of clients, since such solicitations were likely to mislead. On the other hand, in In re R.M.J., ${ }^{6}$ the Supreme Court struck down a Missouri rule that permitted attorneys to only advertise information contained in ten identifiable categories. ${ }^{7}$ Other Supreme Court rulings permitted attorneys to

\footnotetext{
${ }^{3}$ The relevant facts of the Bates case, derived from Cox (1989: p. 135-43), are as follows. The appellants were two recent admittees of the Arizona Bar who started their own legal clinic. Their business model was to provide legal services to individuals with limited means and routine legal problems. The clinic charged legal fees below that of most other firms and relied on heavy volume to survive. However, after two years of struggling to obtain sufficient revenue, the duo were faced with a difficult decision - either go bankrupt, or engage in costly advertising and face potential disbarment. They chose the latter and placed an advertisement in The Arizona Republic, a local newspaper. Roughly one week later, a disciplinary proceeding was initiating against them, and a Special Local Administrative Committee of the State Bar of Arizona recommended that they face a six-month suspension. The Board of Governors of the State Bar of Arizona did not heed to the recommendation and a suspension of one week was imposed. After an unsuccessful challenge at the Arizona Supreme Court, see In re Bates, 555 P.2d 640 (Ariz. 1976), the sanctioned attorneys appealed to the United States Supreme Court, where the Arizona advertising prohibition was struck down as unconstitutional and it was held that attorney advertising was a protected form of commercial free speech. The court argued that legal services advertising "serve[d] to inform the public of the...prices of products and services, and thus perform[ed] an indispensable role in the allocation of resources" Bates, 533 U.S. at 364.

${ }^{4}$ See McChesney (1985) and McChesney (1997) for discussions on this topic.

5436 U.S. 447 (1978). Perhaps most alarming about the Ohralik case was the sanctioned attorney's use of a concealed tape recorder to obtain an accident victim's assent to legal representation.

${ }^{6} 455$ U.S. 191 (1982).

7 The Missouri rule only permitted attorney advertising to contain the lawyer's name, address and telephone number, areas of practice, date and place of birth, schools attended, foreign language ability, office hours,
} 
target classes of persons with advertisements, including individuals charged with drunken driving offenses, ${ }^{8}$ women who had been sterilized in order to receive medical assistance, ${ }^{9}$ and persons against whom foreclosure suits had been filed. ${ }^{10}$ These rulings aside, temporal restrictions on soliciting business from targeted victims have been upheld as constitutional. ${ }^{11}$ All in all, the Central Hudson test now governs the constitutionality of attorney advertising restrictions. $^{12}$

As expected, attorney advertising expenditures grew in the aftermath of Bates. In the fifteen years following the Bates decision, attorney television advertising expenditures increased from less than $\$ 100,000$ to more than $\$ 113$ million in 1992 (Cutler, Moberg, and Schimmel, 1999: p. 1). In fact, in 1992 alone, thirteen law firms budgeted more than $\$ 1$ million per year on television advertising (Cutler, Moberg, and Schimmel, 1999: p. 1). By the start of the $21^{\text {st }}$ century, attorney television advertising outlays totaled approximately $\$ 236$ million. ${ }^{13}$ This number increased to approximately $\$ 493$ million in 2009 . Print media, including magazines and newspapers, accounted for approximately $\$ 102$ million in advertising expenditures the same year, with the internet and radio accounting for roughly another $\$ 13$ million. Clearly, the use of advertising by attorneys, especially with respect to television advertising, has been increasing in recent memory. Figure 1 illustrates this trend for three major advertising mediums (television, print media, and radio/internet) for the first decade of the $21^{\text {st }}$ century.

fee for an initial consultation, availability of a schedule of fees, credit arrangements, and the fixed fee for "routine" legal services.

${ }^{8}$ See Zauderer v. Office of Disciplinary Counsel of Supreme Court, 471 U.S. 626 (1985).

${ }^{9}$ See In re Primus, 436 U.S. 412 (1978).

${ }^{10}$ See Shapero v. Kentucky Bar Association, 486 U.S. 466 (1988).

${ }^{11}$ See Florida Bar v. Went For it, Inc., 515 U.S. 618 (1995), where the United States Supreme Court held that a thirty-day restriction on soliciting business from known accident victims was constitutional.

${ }^{12}$ The Central Hudson test holds that that "[c]ommercial speech that is not false or deceptive and does not concern unlawful activities... may be restricted only in the service of a substantial governmental interest, and only through means that directly advance that interest." Central Hudson Gas \& Electric Corp. v. Public Service Commission of New York, 447 U.S. 557, 566 (1980).

${ }^{13}$ These data courtesy of Kanter-TNS. For more information, visit the Television Bureau of Advertising at http://www.tvb.org. 
Advertising expenditures may have been even higher had many state bars not promulgated regulations, as permitted by Bates and its progeny, on attorney advertising. These regulations, in line with the current state of Constitutional law, are generally aimed at protecting the public from false, deceptive, or misleading advertisements. An in-depth review of each state's attorney advertising restrictions is beyond the scope of this paper. ${ }^{14}$ But of particular relevance to this paper are the numerous ethical regulations that are capable of reducing attorney advertising intensity by raising its marginal cost. Consider, for instance, filing requirements. States including Connecticut, Florida, Kentucky, Louisiana, Mississippi, Nevada, and South Dakota require a prior filing and state bar approval for most attorney advertisements, and in some instances, the filing must be accompanied by a fee. For example, Florida requires an attorney to submit a copy of each advertisement, a corresponding transcript, and a filing fee of $\$ 150$ to the Florida State Bar prior to the dissemination of an advertisement. ${ }^{15}$ The Kentucky and Mississippi bars have adopted similar provisions, though the filing fee is only $\$ 50$ dollars in the case of the former, ${ }^{16}$ and $\$ 25$ in the case of the latter. ${ }^{17}$ These restrictions, among a number of other ethical regulations, are capable of increasing the marginal cost of advertising to law firms, and in the end, ought to decrease attorney advertising intensity.

Despite these ethical restrictions, the increased incidence of attorney advertising since Bates suggests that advertising is an effective means for firms to generate revenue by increasing caseloads. But large firm caseloads arguably impose substantial litigation-related costs upon the

${ }^{14}$ See "Differences between State Advertising and Solicitation Rules and the ABA Model Rules of Professional Conduct" (March 12, 2010), available at http://www.abanet.org/cpr/professionalism/stateadvertising.pdf.

${ }_{15}$ See Florida Rule 4-7.7.

${ }^{16}$ See Kentucky SCR 3.130 (7.05-7.07).

${ }^{17}$ See Mississippi Rule 7.5(a). 
system. ${ }^{18}$ These costs include the private costs of litigation, in addition to those costs that are not compensated by parties to an action, like judicial salaries (wages paid to judges, clerks, and marshals), court and law library maintenance, and others. Presumably, law firms do not fully internalize these litigation costs when choosing advertising intensity. At the same time, however, attorney advertising induces injurers to exercise care since it is unlikely that victims will not pursue a legal remedy. These offsetting effects must be taken into account in determining the optimal level of attorney advertising.

\section{The ECONOMics OF AdVERTISING}

There is a rich history regarding the economics of advertising. Previous attempts to explain the social desirability of advertising were marred by the presumption that advertising increased consumer demand by altering an individual's preferences. ${ }^{19}$ Stigler (1961) avoided this taste-shifting presumption by treating advertising as a medium to provide information about the prices and qualities of products. By reducing consumer search costs, Stigler (1961) concluded that advertising was beneficial in markets with homogenous goods. ${ }^{20}$ Thereafter, Telser (1964) similarly reasoned that advertising was an important source of information and found that there was a positive correlation between advertising and competition. Butters (1976) treated advertising as information, such that consumers learned the "address" of producers at no cost to themselves via advertising. Along the same lines, in markets composed of non-

${ }^{18}$ It should be noted that despite the increases in attorney advertising outlays identified in Figure 1, tort filings actually declined between 1998 and 2007. Specifically, the National Center for State Court's Court Statistics Project recognizes that tort caseloads in 14 general jurisdictions reduced from 272,376 in 1998 to 207,158 in 2007 (a decrease of about 24\%). However, it was concluded that the reduction in tort caseloads was probably not the result of decreased filings. To the contrary, declining tort caseloads were probably the result of higher clearance rates.

${ }^{19}$ Chamberlin (1933: p. 119-20) claimed that advertising altered individual tastes by "exploiting the laws of psychology.” But as Dixit and Norman (1978) recognize, altering an individual's tastes does not necessarily improve social welfare. See Stivers and Tremblay (2005) for a brief history of the social desirability of advertising.

${ }^{20}$ Recently, Norman, Pepall, and Richards (2008) argued that there are inefficiently low levels of advertising for homogenous goods since producers can free-ride on the advertising of competitors. 
homogenous goods, Nelson (1970) and Nelson (1974) argued that advertising provided valuable information to consumers by making them aware of substitutes, which created more elastic demand curves. ${ }^{21}$

Under Nelson's paradigm, goods can be classified as either search or experience goods. Search goods can be inspected for quality before purchase, while experience goods can only be evaluated ex post. Accordingly, a pair of shoes is an example of a search good, while vehicles or other big-ticket items are examples of the latter. However, legal services likely do not fit into either of these categories since consumers probably have difficulty evaluating the quality of legal services before and after consumption.

Darby and Karni (1973) provide helpful insight. They introduce a third area of goods those that have "credence" qualities, or characteristics that cannot be understood by a non-expert, even after consumption. Specifically, "[c]redence qualities are those which, although worthwhile, cannot be evaluated in normal use. Instead the assessment of their value requires additional costly information" (Darby and Karni, 1973: pp. 68-69). The removal of a diseased appendix is an example of a credence good (or, in this case, a credence service). Legal services, due to their apparent complexity to the non-expert, probably fit within this category. Since legal services are perceived as highly complex, consumers may be unaware of the existence or quality of legal services. Indeed, as Cox (1989: p. 140), Stephen and Love (1999: p. 989), and Emons (1977: p. 376) maintain, legal services most likely have these credence qualities. ${ }^{22}$ Therefore, in this paper, it is presumed that attorney advertising provides information regarding the existence

${ }^{21}$ It should be noted that the neoclassical theory of advertising-as-information generally stood in opposition to the theory that advertising created barriers to entry which stifled competition. This paper looks at the effects of advertising by a single firm and therefore the barriers-to-entry approach is ignored. Nonetheless, Comanor and Wilson (1979) provide an excellent survey on the history of the barriers-to-entry approach to advertising.

${ }_{22}$ A popular theme among the credence-goods literature is whether consumers may be exploited by producers. See Emons (1977). The possibility of exploitation by law firms is not addressed in this paper. 
of legal services, which increases consumer demand. ${ }^{23}$ To this end, attorney advertising and legal services are complements. ${ }^{24}$

Despite the recognition that legal services have credence qualities, the theoretical literature is devoid of any formal attempts to analyze the welfare implications of attorney advertising. ${ }^{25}$ Nonetheless, a number of papers focus on the empirical impact of attorney advertising on the price and quality of legal services. Cebula (1998) utilizes ordinary least squares to conclude that lawyer advertising raises the image of lawyers. Since attorney advertising reduces the price of legal services, low income groups (e.g., young individuals and the poor) are better able to obtain legal representation. As a result, advertising allows the legal profession to "shed its 'elitist' image" (Cebula, 1998: p. 505). Along the same lines, McChesney and Muris (1979) compare data from a high-advertising personal injury law firm and its direct low-advertising competitors in the Los Angeles area to find that advertising decreases the price and increases the quality of legal services. Another study concluded that the deregulation of advertising has lead to lower prices for legal services in the United Kingdom, see Love, et al. (1992), which supports the view of advertising-as-information with respect to the impact of media advertising on legal fees (Stephen, 1994). In addition, Domberger and Sherr (1989) find a direct relationship between the quality of legal services and deregulation. Similarly, Schroeter, Smith, and Cox (1987) find that attorney advertising increases competition in the legal services industry. On the other hand, Murdock and White (1985) and Cox, Schroeter, and Smith (1986) conclude that attorney advertising actually leads to a lower quality for legal services.

${ }^{23}$ Incidentally, Cox (1989) notes that due to asymmetric information between buyers and sellers, attorneys may be perceived as "lemons" under Akerlof's (1970) model. However, recognizing that lawyers must pass state examinations, Leland (1979) argues that licensing helps reduce the likelihood of Akerlof's lemons problem.

${ }^{24}$ Cf. Becker and Murphy (1993) who reason that advertisements and goods are complements.

${ }^{25}$ Stephen (1994) models price discrimination in the market for legal services but does not provide a social welfare analysis. 
Nevertheless, all of these papers were empirical in nature. ${ }^{26}$ The theoretical model developed in this paper contributes to the existing literature by being the first to model the welfare implications of attorney advertising.

\section{TheORETICAL MODEL}

Under this simple theoretical model, advertising is treated as solely informational. Its function is to inform victims on the existence of legal services. A law firm acts as the Stackelberg leader by advertising to a pool of potential victims who, with some probability, will utilize a law firm's services if injured. An injurer follows by choosing its level of care. This model arguably mirrors the current state of attorney advertising (where attorneys routinely target an audience of potential personal injury victims) and is described as follows. ${ }^{27}$

Suppose that there is a population of $N$ potential tort victims, each of whom share the same preferences and, in the event of an accident, suffer the same level of damages, $L$. It is presumed that if injury occurs, a victim will not obtain compensation unless the services of an attorney are utilized. That is, the cost to a victim of acquiring sufficient knowledge or information to litigate its own claim (without the services of an attorney) exceeds its level of damages. This presumption is consistent with the observation that legal services have credence

${ }^{26}$ It should be noted that a number of papers focus on the empirical impact of advertising restrictions in professional areas other than legal services. Benham (1972) found evidence of higher prices for eyeglasses in states with advertising restrictions. Similarly, Feldman and Begun (1978) and Feldman and Begun (1980) determined that advertising restrictions raised the price of optician and optometric services. Along the same lines, Kwoka (1984) concluded that the quality of eye examinations was higher in states without advertising restrictions. With respect to pharmaceutical goods, Cady (1976) found higher prices in states with advertising bans on prescription drugs.

Interestingly, the results of both the Benham (1972) and Cady (1976) studies were introduced into evidence during direct examination before the Special Local Administrative Committee of the State Bar of Arizona in the Bates case (Cox, 1989: p. 142).

${ }^{27}$ The conclusions contained herein are preserved even when the injurer is the Stackelberg leader, i.e., when the representative law firm acts as an "ambulance chaser," or seeks out an accident and subsequently advertises to victims. 
qualities. Without loss of generality, normalize $N=1$. In other words, generalize the model to presume one representative potential victim.

Suppose that there is one representative law firm. ${ }^{28}$ Assume that when the law firm's legal services are utilized, litigation occurs with certainty. The law firm represents injured victims since the private benefits of representation outweigh the private costs. The benefit of representing an injured victim is attorney's fees. Presume that attorney's fees are generated on a contingency fee basis, which is a fraction, $h$, of the victim's damages, where $h \in(0,1){ }^{29}$ Despite the existence of only one law firm, consider $h$ to be exogenous. The attorney's fee generated from litigating an injured victim's case is therefore $h L$. The costs facing the firm by representing an injured victim are litigation expenses represented by $c_{V}$, where $c_{V}>0$. It is presumed that $h L>c_{V}$, i.e., the benefit of representing an injured victim outweighs the cost.

The potential victim is either aware or unaware of the representative law firm. Let $\mu$ represent the probability that the potential victim is aware of the representative law firm, regardless of its advertising intensity, where $0<\mu<1$. This potential aware victim hires the law firm if and only if the victim is injured. Next, assume that if the potential victim is unaware of the representative law firm, it chooses to hire the law firm if and only if it is injured and exposed to the law firm's advertising. ${ }^{30}$

The representative law firm acts as the Stackelberg leader and chooses a non-negative advertising intensity, $A$, to maximize profit. This advertising intensity reflects the frequency of

${ }^{28}$ Since there is only one law firm providing a legal service, the optimal level of attorney advertising is not contingent upon service differentiation. See Christou and Vettas (2008) (concluding that the optimal level of advertising depends on the degree of product differentiation).

${ }^{29}$ For a discussion of the impact of contingency fees on the frequency of litigation, see Miceli (1994) and Miceli and Segerson (1991).

${ }^{30}$ This presumption is consistent with the finding that consumers are most concerned with the knowledge and skill of a law firm in choosing its legal services. Indeed, a survey by Cutler, Moberg, and Schimmel (1999) indicated that consumers placed more importance on the knowledge and skill portrayed in an attorney's advertisement than on a firm's commitment to caring, values, or courtesy. 
identical messages disseminated by the firm. The potential victim is not exposed to the firm's advertising with certainty. Accordingly, assume that the probability that the potential victim is exposed to the law firm's advertising, $\alpha(A)$, is increasing in intensity, where $\alpha^{\prime}(A)>0$, $\alpha^{\prime \prime}(A)<0, \alpha(0)=0$ and $\alpha(A) \in[0,1]{ }^{31}$ The probability that the victim, if injured, hires the law firm is given by the expression:

$$
S(A)=\mu+(1-\mu) \alpha(A)
$$

where $S(0)=\mu$. Changes in $S(A)$ occur solely because the representative law firm advertises in an attempt to lure an unaware victim to utilize the firm's legal services.

Now suppose that there is one representative injurer who acts as the Stackelberg follower. The representative injurer minimizes the expected costs associated with care. The costs of care include $x$, the monetary cost of care, and the corresponding level of expected civil liability. Let $p(x)$ represent the probability of an accident as a function of the monetary cost of care, where $p^{\prime}(x)<0, p^{\prime \prime}(x)>0$. Figure 2 is a flow chart depicting the game between the representative law firm, injurer, and victim.

Since the representative injurer is the Stackelberg follower, it first chooses its level of care. Assuming strict liability, the injurer faces liability for $p(x) S(A)$ accidents. Then, the injurer's cost of exercising care in the absence of court error is:

$$
x+p(x) S(A)\left[L+c_{I}\right]
$$

${ }^{31}$ Although the theory does not depend on a precise value for $\alpha(A)$, it should be noted that in the realm of television advertising, $\alpha(A)$ is probably close to one. In an interesting marketing survey, Parkinson and Neeley (2003) found that $94 \%$ of respondents had seen a television advertisement for legal services. However, the probability that a respondent chose to utilize the legal services of an advertising attorney was not uniformly distributed across income, education, and racial background. In fact, they found a significant inverse correlation $(p$ $<.01)$ between the respondent's income and education and the choice to utilize the legal services of an advertising attorney. A similar inverse relationship was found $(p<.05)$ between hiring an advertising attorney and Caucasian background. 
where $c_{I}$ represents the litigation costs borne by the injurer. ${ }^{32}$ That is, the cost of care is the sum of the monetary cost of care and the expected civil liability stemming from the probability that the injured victim hires the representative law firm.

The injurer's problem is to minimize the expected costs of care, i.e.,

$$
\min _{x} x+p(x) S(A)\left[L+c_{I}\right]
$$

The solution to (3) implies that the injurer will choose $x$ such that:

$$
-p^{\prime}(x) S(A)\left[L+c_{I}\right]=1
$$

Let $x^{*}(A)$ represent the solution to (4). ${ }^{33}$ Notice that the injurer only internalizes the harm caused to a victim who brings suit. Therefore, the injurer's care choice reflects the possibility that it will sometimes escape liability. ${ }^{34}$ Notice too that when litigation occurs, the injurer does not internalize the victim's litigation costs.

The representative law firm chooses an advertising intensity to maximize profit, $\pi$. Assume that labor and capital are fixed, such that profit is only a function of the level of advertising. Then, the firm's profit function can be stated as:

$$
\pi(A)=p\left(x^{*}(A)\right) S(A)\left[L h-c_{v}\right]-z A
$$

where $z$ is the unit cost of advertising and $p(x) S(A)$ is the probability that an injured victim will utilize the law firm's services. The law firm's problem is to maximize profit by its choice of advertising intensity, i.e.:

\footnotetext{
${ }^{32}$ It is presumed that victims will be able to establish damages greater than pure compensation in the event the injurer fails to go to court.

${ }^{33}$ From (7), care is increasing in advertising intensity, but with decreasing marginal returns, i.e.:

and:

$$
\frac{\partial x^{*}(A)}{\partial A} \geq 0
$$$$
\frac{\partial x^{* 2}(A)}{\partial A^{2}}<0
$$

${ }^{34}$ The imposition of punitive damages is usually justified to ameliorate this problem.
} 


$$
\max _{A} \pi(A)
$$

The solution to (6) implies that the law firm will choose its advertising level $A^{*}$ such that:

$$
p\left(x^{*}\left(A^{*}\right)\right) S^{\prime}\left(A^{*}\right)\left[L h-c_{v}\right]=-p^{\prime}\left(x^{*}\left(A^{*}\right)\right) S\left(A^{*}\right)\left[L h-c_{v}\right] \frac{\partial x^{*}\left(A^{*}\right)}{\partial A}+z
$$

The result in (7) demonstrates that the firm chooses its advertising intensity by internalizing some of the deterrence that it generates. The left-hand side of (7) is the marginal revenue of advertising intensity. Advertising increases the probability that an injured unaware victim utilizes the law firm's services. The first term on the right-hand side is the marginal reduction in revenue resulting from the deterrent effect of advertising. Advertising induces injurers to exercise care which reduces the probability of harm to the potential victim. The law firm's revenue decreases with this reduction in the probability of injury, and accordingly, the firm perceives this phenomenon as a cost to advertising. The last term on the right-hand side is the marginal cost of advertising.

Now consider the case of attorney advertising from a social perspective. Under this simple model, the social cost of accidents as a function of advertising intensity $(S C)$ is:

$$
S C=x^{*}(A)+p\left(x^{*}(A)\right)\left(S(A)\left[c_{I}+c_{V}\right]+L\right)+z A
$$

The social planner's problem is to minimize the social cost of accidents by choice of advertising intensity, i.e.,

$$
\min _{A} x^{*}(A)+p\left(x^{*}(A)\right)\left(S(A)\left[c_{I}+c_{V}\right]+L\right)+z A
$$

The first-order condition for the equation in (9) is:

$$
\begin{gathered}
\frac{\partial S C}{\partial A}=\left\{1+p^{\prime}\left(x^{*}(A)\right)\left(S(A)\left[c_{I}+c_{V}\right]+L\right)\right\} \frac{\partial x^{*}(A)}{\partial A}+ \\
p\left(x^{*}(A)\right) S^{\prime}(A)\left[c_{I}+c_{V}\right]+z
\end{gathered}
$$


The first term on the right-hand side of (10) is the marginal effect of advertising on the social costs associated with injurer care. The second term is the marginal increase in litigation costs resulting from the ability of advertising to induce additional victims to file suit. The third term is the marginal cost of advertising. Substituting (4), the injurer's first-order condition, into (10) and rearranging yields:

$$
\begin{gathered}
\frac{\partial S C}{\partial A}=p^{\prime}\left(x^{*}(A)\right)\left[S(A) c_{V}+(1-S(A)) L\right] \frac{\partial x^{*}(A)}{\partial A}+ \\
p\left(x^{*}(A)\right) S^{\prime}(A)\left[c_{I}+c_{V}\right]+z
\end{gathered}
$$

Since $p^{\prime}\left(x^{*}(A)\right)<0$ and $\frac{\partial x^{*}(A)}{\partial A}>0$, the first term on the right-hand side is negative, indicating that advertising reduces social costs via its deterrent effect on injurers. In a first-best world, this deterrence benefit would be balanced against the marginal increase in litigation costs and the marginal cost of advertising when determining the socially-optimal level of attorney advertising intensity.

However, the profit-maximizing level of advertising intensity chosen by the representative law firm likely diverges from the first-best level. To illustrate this proposition, substitute (7), the representative law firm's choice of advertising intensity, into (11) and simplify to obtain:

$$
\begin{gathered}
\frac{\partial S C}{\partial A}=p^{\prime}\left(x^{*}(A)\right)[(1-S(A)(1-h)) L] \frac{\partial x^{*}(A)}{\partial A}+ \\
p\left(x^{*}(A)\right) S^{\prime}(A)\left[L h+c_{I}\right]
\end{gathered}
$$

Since the first term on the right-hand side is negative and the second term is positive, the overall expression in (12) is ambiguous in sign. This implies that the representative law firm may be choosing too much or too little advertising from a social perspective. The fact that the first term on the right-hand side is negative indicates that the representative law firm fails to internalize the 
full deterrence benefits of advertising. This is true for two reasons. First, the law firm ignores the damages suffered by victims who do not utilize the firm's services, a fraction of $1-S(A)$ of victims. Second, the law firm internalizes only a fraction $h$ of the damages suffered by victims who utilize the firm's services. Along the same lines, since the second term on the right-hand side is positive, the representative law firm fails to internalize the full social costs of advertising. This occurs for two reasons. First, the law firm ignores the injurer's litigation costs, and second, the law firm's revenue of $L h$ is only a fraction of the victim's damages for each additional case that goes to trial. Since the representative law firm does not fully internalize the social costs and the social benefits of its advertising intensity, it is unclear whether the law firm is advertising excessively or inefficiently low. The manner in which the law firm's actual choice of advertising intensity corresponds to the social optimum is a purely empirical question.

What are the policy implications of this ambiguous result? First, a blanket prohibition on attorney advertising, i.e., $A=0$, likely causes the law firm to advertise at a socially-undesirable level. Except in the extreme case of a corner solution, that is, when all victims are aware of the existence of the law firm (or equivalently, $\mu=1$ ), social costs may be reduced by permitting a positive level of attorney advertising. Particularly, by increasing $A$ away from the origin, the injurer is induced to exercise additional care, which results in beneficial deterrence. Therefore, by permitting law firms to advertise, injurers internalize a greater degree of the harm they are expected to cause. This conclusion, resting on the social deterrence benefit of advertising, is supported by the observation that injurers generally take too little care, even under strict liability, when litigation is costly (Shavell, 1982). Based on this result, the Supreme Court's ruling in Bates is supported by the preceding economic theory. 
Second, even though blanket prohibitions on attorney advertising are likely to be socially-undesirable, regulation on attorney advertising may nevertheless be beneficial. As noted above, the profit-maximizing level of attorney advertising intensity is unlikely to correspond to the social optimum. When law firms are advertising at inefficiently high levels, i.e., when the law firm's choice of advertising intensity is greater than the social optimum, regulation may induce law firms to reduce advertising intensities. This result provides some support for a subset of ethical advertising restrictions implemented by state bars. While it is possible to maintain that these restrictions are promulgated in an effort to preserve the cartel-like nature of the legal services industry, the preceding economic theory provides an alternative rationale. Particularly, when the social costs of advertising are high, restrictions that increase the marginal cost of advertising induce law firms to choose a level of advertising intensity that is closer to the social optimum. As a result, advertising regulations - specifically those which increase the marginal cost of attorney advertising - may be welfare-improving. ${ }^{35}$

\section{E. Conclusion}

Attorneys routinely advertise their legal services. Many of these advertisements target personal injury victims. In this paper, a theoretical model is developed which incorporates attorney advertising intensity, litigation costs, and an endogenous number of lawsuits. It is shown that attorney advertising is capable of inducing injurers to exercise additional care. But, at the same time, advertising increases the number of victims utilizing the civil justice system, which results in an increase in litigation costs. A proper assessment of the optimal level of

${ }^{35}$ As a corollary, when firms are advertising at inefficiently low levels, a subsidy on attorney advertising may be justified. But, given the observation that state bars are more apt to restrict, as opposed to encourage, legal services advertising, it is likely that law firms are actually advertising excessively (given the presumption that state bars are more concerned about social welfare than preserving the legal services cartel). 
attorney advertising requires a trade-off between the benefits of deterrence and the costs of litigation and advertising.

While the preceding economic theory does not provide conclusive evidence of whether firms are advertising excessively or inefficiently low, it provides guidance for policymakers. The theory demonstrates that blanket prohibitions on attorney advertising are suboptimal, which supports the Supreme Court's ruling in Bates. However, it is also shown that when the social costs of advertising are sufficiently high, ethical regulations on attorney advertising may be welfare-improving. 


\section{Figure 1}

\begin{tabular}{|c|c|c|c|}
\hline \multicolumn{4}{|c|}{$\begin{array}{c}\text { Attorney Advertising Outlays, } 2000 \text { to } 2009 \\
\text { CPI adjusted to reflect } 2000 \text { dollars } \\
(\$ 000) \\
\end{array}$} \\
\hline Year & Television & Print Media & $\begin{array}{l}\text { Radio/ } \\
\text { Internet }\end{array}$ \\
\hline 2000 & 236,015 & 47,959 & $627^{36}$ \\
\hline 2001 & 278,535 & 49,685 & 5,337 \\
\hline 2002 & 324,765 & 47,517 & 4,394 \\
\hline 2003 & 323,532 & 54,628 & 8,631 \\
\hline 2004 & 348,686 & 54,166 & 6,861 \\
\hline 2005 & 342,579 & 52,612 & 14,283 \\
\hline 2006 & 358,741 & 54,595 & 6,099 \\
\hline 2007 & 352,512 & 80,662 & 3,020 \\
\hline 2008 & 373,696 & 79,633 & 3,907 \\
\hline 2009 & 394,243 & 81,798 & 10,110 \\
\hline
\end{tabular}

Figure 2

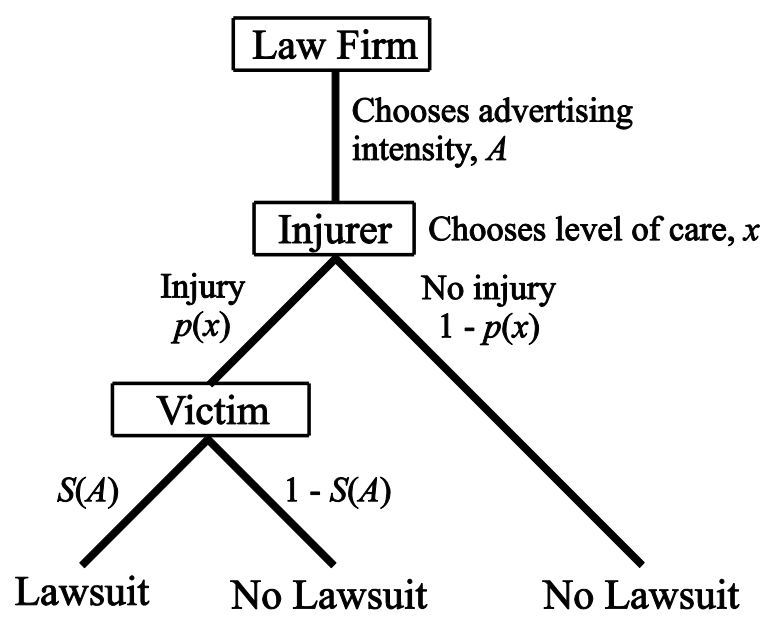

\footnotetext{
${ }^{36}$ Data on internet advertising expenditures were unavailable for this year.
} 


\section{REFERENCES}

Akerlof, George. 1970. The Market for "Lemons": Quality Uncertainty and the Market Mechanism. Journal of Political Economy 84: 488-500.

Becker, Gary S. and Kevin M. Murphy. 1993. A Simple Theory of Advertising as a Good or Bad. Quarterly Journal of Economics 108: 941-64.

Benham, Lee. 1972. The Effects of Advertising on the Price of Eyeglasses. Journal of Law and Economics 15: 337-51

Butters, Gerard R. 1976. A Survey of Advertising and Market Structure. American Economic Review 66: 392-97.

Cady, John F. 1976. An Estimate of the Price Effects of Restrictions on Drug Price Advertising. Economic Inquiry 14: 493-510.

Calvani, Terry, James Langenfeld, and Gordon Shuford. 1988. Attorney Advertising and Competition at the Bar. Vanderbilt Law Review 41: 761-88.

Cebula, Richard J. 1998. Does Lawyer Advertising Adversely Influence the Image of Lawyers in the United States? An Alternative Perspective and New Empirical Evidence. Journal of Legal Studies 27: 503-16.

Chamberlin, Edward. 1933. The Theory of Monopolistic Competition. Cambridge, MA: Harvard University Press.

Christou, C. and Vettas, N. 2008. On Informative Advertising and Product Differentiation. International Journal of Industrial Organization 26: 92-112.

Comanor, William S. and Thomas A. Wilson. 1979. The Effect of Advertising on Competition: A Survey. Journal of Economic Literature 17: 453-76

Cox, Steven R. 1989. Advertising Restrictions among Professionals: Bates v. State Bar of Arizona, in The Antitrust Revolution: The Role of Economics. Longman Higher Education.

, John R. Schroeter, and Scott L. Smith. 1986. Attorney Advertising and the Quality of Routine Legal Services. Review of Industrial Organization 2: 340-54.

Cutler, Bob D., Chris Moberg, and Kurt Schimmel. 1999. Attorney Advertising: The Link Between Ad Cues and Consumer Search Criteria. Journal of Professional Services Marketing 9: $1-14$.

Darby, Michael R. and Edi Karni. 1973. Free Competition and the Optimal Amount of Fraud. Journal of Law and Economics 16: 67-88. 
Dixit, Avinash and Victor Norman. 1978. Advertising and Welfare. Bell Journal of Economics 9: $1-17$.

Domberger, Simon and Avrom Sherr. 1989. The Impact of Competition on Pricing and Quality of Legal Services. International Review of Law and Economics 9: 41-56.

Emons, Winand. 1977. Credence Goods Monopolists. International Journal of Industrial Organization 19: 375-89.

Feldman, Roger D. and James W. Begun. 1978. The Effects of Advertising Restrictions-Lessons from Optometry. Journal of Human Resources 13: 247-62.

and Variance of Prices? Economic Inquiry 18: 487-92.

1980. Does Advertising of Prices Reduce the Mean

Kwoka, John E., R. 1984. Advertising and the Price and Quality of Optometric Services. American Economic Review 74: 211-216.

Leland, Hayne E. 1979. Quacks, Lemons and Licensing: A Theory of Minimum Quality

Standards. Journal of Political Economy 87: 1328-46.

Lidsky, Lyrissa B. and Tera J. Peterson. 2008. Medium-Specific Regulation of Attorney Advertising: A Critique. Florida Journal of Law and Public Policy, forthcoming (available at http://papers.ssrn.com/sol3/papers.cfm?abstract_id=1021278).

Love, James H., Frank Stephen, Derek Gillanders, and Alan Paterson. 1992. Spatial Aspects of Deregulation in the Market for Legal Services. Regional Studies 26: 127-147.

McChesney, Fred S. 1985. Commercial Speech in the Professions: The Supreme Court's Unanswered Questions and Questionable Answers. University of Pennsylvania Law Review 134: $45-119$.

. 1997. De-Bates and Re-Bates: The Supreme Court's Latest Commercial Speech Cases. Supreme Court Economic Review 5: 81-139.

and Timothy J. Muris. 1979. Advertising and the Price and Quality of Legal Services: The Case for Legal Clinics. American Bar Foundation Research Journal 4: 179207.

Miceli, Thomas J. 1994. Do Contingency Fees Promote Excessive Litigation? Journal of Legal Studies 23: 211-24.

and Kathleen Segerson. 1991. Contingent Fees for Lawyers: The Impact on Litigation and Accident Prevention. Journal of Legal Studies 20: 381-99. 
Murdock, G.W. and Jim White. 1985. Does Legal Service Advertising Serve the Public's Interest? A Study of Lawyer Ratings and Advertising Practice. Journal of Consumer Policy 8: $153-65$.

Nelson, Phillip. 1970. Information and Consumer Behavior. Journal of Political Economy 78: 311-29. 1974. Advertising as Information. Journal of Political Economy 82: 729-54.

Norman, George, Lynne Pepall, and Dan Richards. 2008. American Journal of Agricultural Economics 90:719-32.

Parkinson, Michael G. and Sabrina Neeley. 2003. Attorney Advertising. Services Marketing Quarterly 24: 17-28.

Schroeter, John R., Scott L. Smith, and Steven R. Cox. 1987. Advertising and Competition in Routine Legal Service Markets: An Empirical Investigation. Journal of Industrial Economics 36: 49-60.

Shavell, Steven. 1982. The Social versus the Private Incentive to Bring Suit in a Costly Legal System. Journal of Legal Studies 11:333-339.

Stephen, Frank H. 1994. Advertising, Consumer Search Costs and Prices in a Professional Service Market. Applied Economics 26: 1177-88.

and James H. Love. 1999. Regulation of the Legal Professions. Encyclopedia of Law and Economics 5860: 987-1017 (available at http:// encyclo.findlaw.com/5860book.pdf).

Stigler, George. 1961. The Economics of Information. Journal of Political Economy 69: 213-25.

Stivers, Andrew and Victor J. Tremblay. 2005. Advertising, Search Costs, and Social Welfare. Information Economics and Policy 17: 317-33.

Telser, Lester G. 1964. Advertising and Competition. Journal of Political Economy 6: 537-62. 